\title{
CD3EAP wt Allele
}

National Cancer Institute

\section{Source}

National Cancer Institute. CD3EAP wt Allele. NCI Thesaurus. Code C54332.

Human CD3EAP wild-type allele is located in the vicinity of $19 q 13.3$ and is approximately 5 $\mathrm{kb}$ in length. This allele, which encodes DNA-directed RNA polymerase I subunit RPA34, plays a role in the transcription of ribosomal RNA. 